\title{
Maximizing the efficiency of residents operating room scheduling: a case study at a teaching hospital
}

\author{
Daniel Bouzon Nagem Assad ${ }^{\mathrm{a}, \mathrm{b} *}$ (D), Thais Spiegel ${ }^{\mathrm{a}}$ (D) \\ aUniversidade do Estado do Rio de Janeiro, Rio de Janeiro, RJ, Brasil \\ bUniversidad Politécnica de Madrid, Madrid, España \\ *danielbouzon@gmail.com
}

\begin{abstract}
Paper aims: To find efficient operation room scheduling for residents considering several resources constraints and ensuring a minimum number of surgeries for approval in the training program.

Originality: We find no research in current literature addressing operation room resource allocation for residents training in order to meet legislation approval criteria.

Research method: The number of procedures to be performed by each resident was defined by Brazilian legislation and by the rules obtained from interviews with the chief professor of a vascular hospital. To solve the allocation of doctors to surgeries planning problem, also addressed in literature as Master Surgical Schedule (MSS), we propose a mathematical programming approach.

Main findings: The mathematical model showed that some of the current rules of resource availability bring about infeasible planning when trying to achieve the legislation quantitative rules for the residents training.

Implications for theory and practice: The model allowed the decision maker to plan and schedule vascular surgeries in a better and faster way, through an automated system, instead of allocating residents to surgeries manually, which takes many hours per month. Furthermore, changing the input data in the proposed model can allow other hospitals or specialists to get efficient results in less time.
\end{abstract}

Keywords

Scheduling; master surgical scheduling. Mathematical programming. Vascular surgery. Hospital.

How to cite this article: Assad, D. B. N., \& Spiegel, T. (2019). Maximizing the efficiency of residents operating room scheduling: a case study at a teaching hospital. Production, 29, e20190025. https://doi.org/10.1590/0103-6513.20190025

Received: May. 19, 2019; Accepted: July 9, 2019.

\section{Introduction}

Vascular diseases are serious illnesses - their treatment is complex and requires specialized surgical procedures, which are performed in tertiary health centers. In order to perform these procedures, sophisticated equipment, qualified teams and intensive care units (ICU) prepared for the postoperative period are necessary. The increase in the life expectancy of a population causes a higher prevalence of this type of disease, which has imposed a significative burden to the Brazilian Unified Health System (SUS) (Mendes et al., 2014).

According to Barbagallo et al. (2015), offering a better quality of service with limited resources, and at a lower cost, is a global health challenge. This makes the goal of optimization a central theme in modern hospital management, as it allows for increases in resource efficiency through the development of advanced methods to plan and program the hospitals' processes. On the other hand, residents have to fulfill a number of specific procedures as part of their educational requirements facing many variabilities. This may result in a high amount of overtime hours to succeed in each stage of their educational process and bring negative effects that decrease the quality of provided care (Erhard et al., 2018). 
In this context, a teaching hospital deals with a challenge: increasing resource efficiency planning while subject to several rules from various regulational requirements (from the Ministry of Health, the Ministry of Education and various professional councils) (Assad et al., 2018a). Therefore, to achieve an efficient planning of resident allocation, we propose a mathematical programming approach. This technique associates the annual minimum number of surgeries that must be realized by each resident to operating room planning, through optimal resource allocation.

\section{Theoretical background: hospital management and operating room planning}

In several regions of the world, health care industry is facing a dilemma due, on one hand, to the poor quality standards of services offered and, on the other hand, to strong pressure to increase efficiency and productivity, and to reduce costs (Vähätalo \& Kallio, 2015; Spiegel \& Assad, 2018).

Optimization issues in healthcare have received considerable attention for over three decades. More recently, however, with declining birth rates in almost all developed countries, and increasing average longevity overall, optimization issues in healthcare have become notoriously important, attracting research institutions and great social interest. Over the years, attention has gradually expanded from resource allocation and strategic planning to include operational issues, such as resource scheduling and treatment planning (Rais \& Viana, 2011; Silva et al., 2018; Assad et al., 2018b).

According to Barbagallo et al. (2015), hospital budgets account for almost half of all expenditures in most health systems, and the most important reasons for hospital admission are procedures or surgical interventions.

Van Sambeek et al. (2010) categorize decision-making models related to design and control processes that involve patient flows in hospitals. The authors' objective is to map out how hospitals try to achieve the goals of higher quality and higher resource allocation efficiency in the field of operations management (OM) and operational research (OR). The synthesis of this categorization is presented in Table 1 .

Table 1. Optimizing hospital processes models: classifications and categories.

\begin{tabular}{|c|c|}
\hline Classifications & Categories \\
\hline \multirow[t]{3}{*}{ Type of model } & Computer simulation \\
\hline & Descriptive \\
\hline & Analytical \\
\hline \multirow[t]{3}{*}{ Type of problem } & Process Design \\
\hline & Capacity problem \\
\hline & Scheduling problem \\
\hline \multirow[t]{5}{*}{ Kind of department } & Operating room \\
\hline & Inpatient \\
\hline & Outpatient \\
\hline & Imaging diagnosis \\
\hline & Other \\
\hline \multirow[t]{4}{*}{ Objective of study } & Designing a model \\
\hline & Comparing models \\
\hline & Using a model \\
\hline & Critiquing/ proposing a model \\
\hline \multirow[t]{5}{*}{ Outcome measures } & Waiting times \\
\hline & Needed capacity \\
\hline & Cost \\
\hline & Utilization \\
\hline & others \\
\hline Validated in practice & Yes/no \\
\hline Generic & Yes/no \\
\hline
\end{tabular}

Source: adapted from Van Sambeek et al. (2010).

Abdelrasol et al. (2014) state that operating room planning can be divided into 3 decision levels: (i) case mix problem, (ii) master surgical scheduling and (iii) surgery scheduling. The last decision level can be broken down into (1) operational offline and (2) operational online (Hulshof et al., 2012). According to Assad (2017), the decision level and types of decisions taken in each are as summarized in Table 2. The relation between operating room planning and decision support techniques in the OM \& OR contexts is syntetized in Figure 1. 


\begin{tabular}{|c|c|c|c|}
\hline Decision level & Planning horizon & Type of problem & Decisions taken \\
\hline Strategic & 1 year & Case mix Problem (CMP) & Decide which surgeries will be offered by the hospital \\
\hline Tactical & 1,2 or 3 months & $\begin{array}{l}\text { Master Surgical Schedule } \\
\text { Problem (MSSP) }\end{array}$ & $\begin{array}{l}\text { Define which surgeon (or specialty) will be allocated in which rooms in a } \\
\text { time horizon. }\end{array}$ \\
\hline Operational Off-line & Week or day & $\begin{array}{l}\text { Surgical Case Assigment } \\
\text { Problem (SCAP) }\end{array}$ & $\begin{array}{l}\text { Allocate each surgeon to each surgery on days defined by the MSSP and } \\
\text { define order of execution. }\end{array}$ \\
\hline Operational Online & Hours & Rescheduling & $\begin{array}{l}\text { Rescheduling when unplanned events occur (dealing with real time } \\
\text { variabilities). }\end{array}$ \\
\hline
\end{tabular}

Source: adapted from Assad (2017)

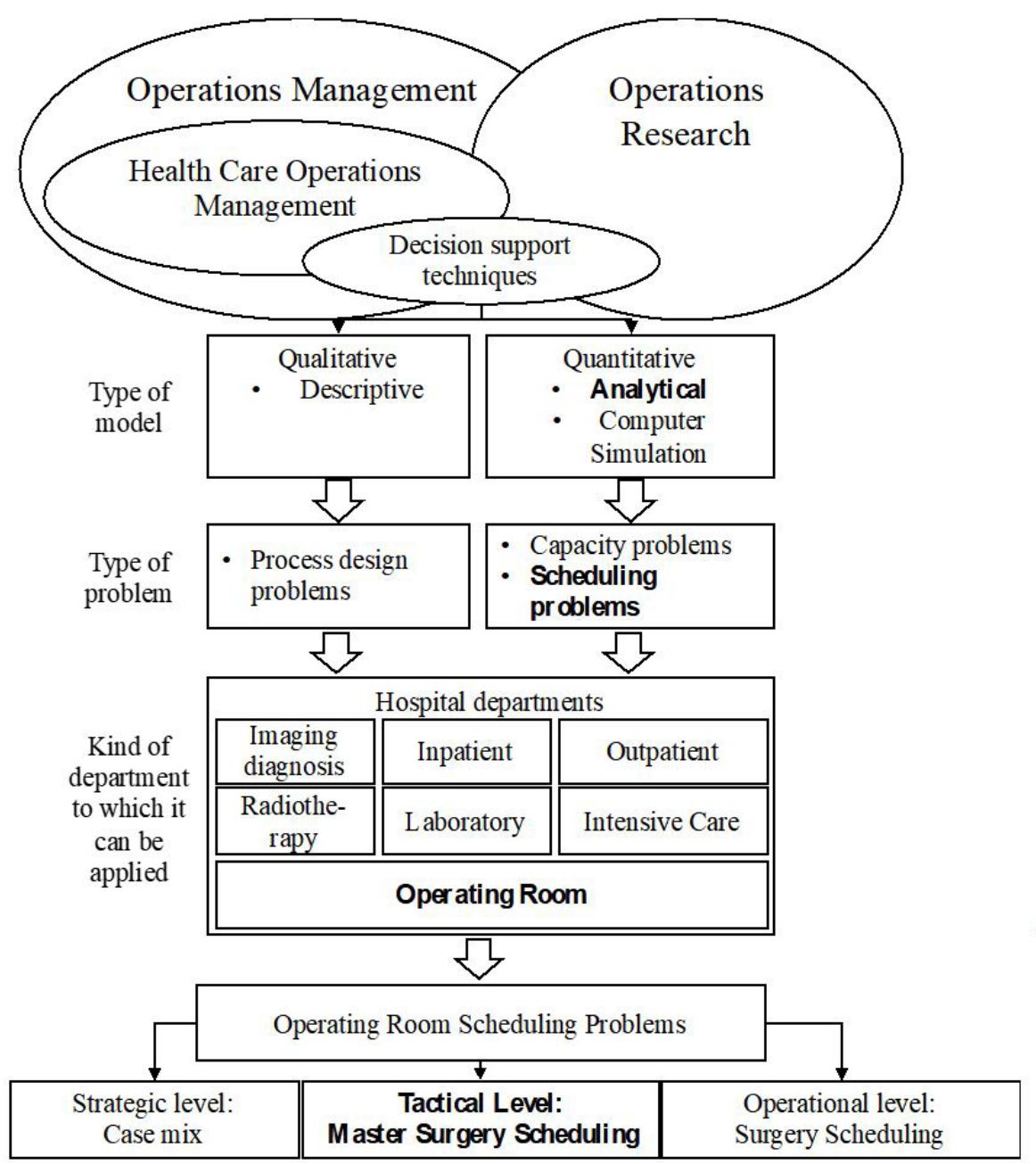

Figure 1. Synthesis of operating room planning literature review. Source: adapted from Assad (2017).

Although mathematical programming models have been widely used to solve Master Surgery Scheduling Problems (Persson \& Persson, 2007; Van Oostrum et al., 2008; Beliën et al., 2009; Wang et al., 2010; Day et al., 2012; He et al., 2012; Paul \& Jotshi, 2013; Sufahani \& lsmail, 2014; Saadouli et al., 2015; Villarreal \& Keskinocak, 2016) there is no research in which quantitative legislation criteria are considered, according to Erhard et al. (2018).

Therefore, in order to cover this literature review gap Assad et al. (2018a) proposed a mixed integer linear programming model and the current research merges it with a brief theoretical background better discussed in Assad (2017) in an enhanced version. 


\section{Research method}

Following the classification proposed by Yin (2001), this research is an exploratory single case study. Its objective is to deepen the comprehension regarding a problem that is not yet sufficiently studied, to suggest hypotheses and questions, or to develop the theory (Miguel, 2007). The case study is divided in three parts: literature review (results presented in Table 3 - see Assad (2017) for more information), resource parametrization and mathematical modelling.

Table 3. Synthesis of literature review on MSSP.

\begin{tabular}{|c|c|c|c|c|c|c|}
\hline Authors & Objective of the model & Constraints considered & $\begin{array}{l}\text { Type } \\
\text { of data } \\
\text { utilized }\end{array}$ & $\begin{array}{l}\text { Planning } \\
\text { horizon }\end{array}$ & $\begin{array}{l}\text { Formulation } \\
\text { of the } \\
\text { optimization } \\
\text { model }^{1}\end{array}$ & $\begin{array}{l}\text { Type of } \\
\text { solution }^{2}\end{array}$ \\
\hline $\begin{array}{l}\text { Persson \& Persson } \\
\text { (2007) }\end{array}$ & $\begin{array}{l}\text { Minimize costs related to } \\
\text { not operating on a patient } \\
\text { considering their priority }\end{array}$ & $\begin{array}{l}\text { sugery room, human } \\
\text { resources, and beds }\end{array}$ & Real data & Weekly & MILP & Exact \\
\hline $\begin{array}{c}\text { Van Oostrum et al. } \\
\text { (2008) }\end{array}$ & $\begin{array}{l}\text { Minimize room allocation } \\
\text { and peaks of bed occupation }\end{array}$ & $\begin{array}{l}\text { sugery room, human } \\
\text { resources, and beds }\end{array}$ & Real data & Weekly & MILP & Heuristic \\
\hline Beliën et al. (2009) & $\begin{array}{l}\text { Minimize the peak of bed } \\
\text { occupation }\end{array}$ & $\begin{array}{l}\text { sugery room, human } \\
\text { resources, and beds }\end{array}$ & Real data & Weekly & MlLP and 1QP & $\begin{array}{l}\text { Exact and } \\
\text { heuristic }\end{array}$ \\
\hline Wang et al. (2010) & $\begin{array}{l}\text { Maximize prioritary surgeries } \\
\text { controlling staff workload }\end{array}$ & $\begin{array}{l}\text { sugery room } \\
\text { and human resources }\end{array}$ & Real data & $\begin{array}{l}\text { Weekly and } \\
\text { offline daily }\end{array}$ & MILP & Heuristic \\
\hline He et al. (2012) & $\begin{array}{l}\text { Minimize costs related to } \\
\text { human resources (nursing) }\end{array}$ & $\begin{array}{l}\text { sugery room and human } \\
\text { resources (nursing) }\end{array}$ & Real data & Weekly & MILP & Exact \\
\hline Day et al. (2012) & $\begin{array}{l}\text { Maximize revenue and staff } \\
\text { satisfaction }\end{array}$ & $\begin{array}{l}\text { sugery room and human } \\
\text { resources }\end{array}$ & Real data & Biweekly & MILP & Heuristic \\
\hline $\begin{array}{l}\text { Jeang \& Chiang } \\
\text { (2012) }\end{array}$ & $\begin{array}{l}\text { Minimize idle time and } \\
\text { overtime }\end{array}$ & $\begin{array}{l}\text { sugery room and human } \\
\text { resources }\end{array}$ & Real data & Biweekly & MINLP & Exact \\
\hline Paul \& Jotshi (2013) & Minimize room allocation & $\begin{array}{l}\text { sugery room and human } \\
\text { resources }\end{array}$ & Real data & $\begin{array}{l}\text { Weekly and } \\
\text { offline daily }\end{array}$ & MILP & Exact \\
\hline $\begin{array}{l}\text { Sufahani \& lsmail } \\
\qquad(2014)\end{array}$ & $\begin{array}{l}\text { Level occupation between } \\
\text { surgery rooms }\end{array}$ & $\begin{array}{l}\text { sugery room and human } \\
\text { resources }\end{array}$ & Real data & Weekly & MILP & Exact \\
\hline $\begin{array}{l}\text { Saadouli et al. } \\
\text { (2014) }\end{array}$ & $\begin{array}{l}\text { Maximize amount of } \\
\text { surgeries }\end{array}$ & $\begin{array}{l}\text { sugery room and human } \\
\text { resources }\end{array}$ & Real data & Weekly & MILP & Exact \\
\hline $\begin{array}{l}\text { Saadouli et al. } \\
\text { (2015) }\end{array}$ & $\begin{array}{l}\text { Maximize amount of } \\
\text { surgeries }\end{array}$ & $\begin{array}{c}\text { sugery room, post- } \\
\text { anesthesia recovery (PAR) }\end{array}$ & Real data & Weekly & MILP & Exact \\
\hline $\begin{array}{c}\text { Villarreal \& } \\
\text { Keskinocak (2016) }\end{array}$ & $\begin{array}{l}\text { Minimize resource allocation } \\
\text { (nursing) }\end{array}$ & budget & Real data & $\begin{array}{l}\text { Yearly (48 } \\
\text { weeks) }\end{array}$ & MILP & Heuristic \\
\hline This article & $\begin{array}{l}\text { Minimize resource } \\
\text { allocation }\end{array}$ & $\begin{array}{l}\text { Surgery room, human } \\
\text { resources, equipment, } \\
\text { blood bags }\end{array}$ & Real data & Annual & MILP & Exact \\
\hline
\end{tabular}

'Optimization models may be formulated in diferent ways, among which stand out the following: integer programming (IP), mixed integer linear programming (MILP), integer quadratic programming (1QP), and mixed integer non-linear programming (MINLP); ${ }^{2}$ Depending on the complexity of the modeling and/or the size of the model, finding the optimal solution, considering all combinations of the feasible solutions space (exact solution) may result in very long resolution times. To avoid long solution times, many authors propose faster solution methods (heuristics), that disconsider part of the feasible solutions space to obtain a solution (not necessarily the optimal one). Source: adapted from Assad (2017).

According to Barbagallo et al. (2015), the management of the surgery center must follow the three steps described in Figure 2. The scope of this research will be limited to the parametrization of resources necessary for the execution of surgeries in the vascular clinic, and to the proposition of optimization models to estimate the relation between resources necessary for respecting the normative instruments that govern surgical services applied to the case of vascular surgery.

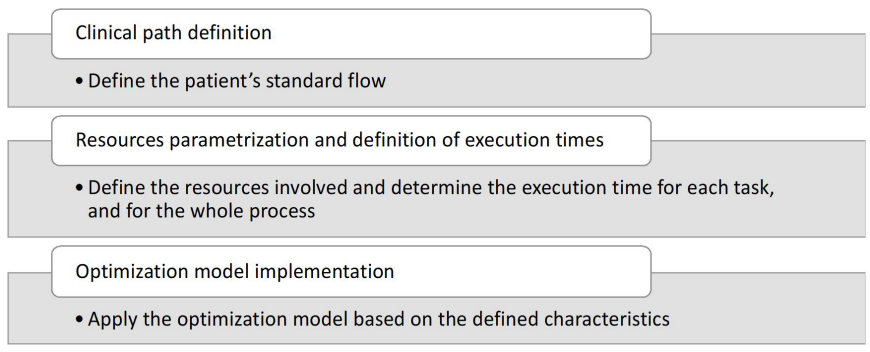

Figure 2. Optimized planning steps for operation room management. Source: adapted from Barbagallo et al. (2015). 


\section{Problem description: vascular surgeries at a teaching hospital}

Teaching hospitals are subject to several rules from many regulational requirements (from the Ministry of Health, the Ministry of Education and various professional councils). Regarding the residency program, the National Comission of Medical Residency (Comissão Nacional de Residência Médica - CNRM) (The specific legislation that governs the residency programs in Brazil is available at (in Portuguese) (Brasil, 2006) and the National Comission of Multiprofessional Healthcare Residency (Comissão Nacional de Residência Multiprofissional em Saúde - CNRMS) stand out. Both define the minimal requirements for obtaining the surgeon license in each specialty. Currently, these minimal requirements are defined by the CNRM Resolution number 02/2006, from May 17th, 2006 (Brasil, 2006). For the vascular surgery specialty, this resolution demands that each resident carries out at least 150 surgeries, with a minimum of 50 arterial surgeries per year of the program, and at least 30\% of small size surgeries, $40 \%$ of medium size surgeries, and $40 \%$ of large size surgeries in a one-year timespan. Differently from other specialties, these numbers are the same for both the general surgeons on the first year of residency in vascular surgery (R1) and for those on the second year (R2). The hospital being studied also offers a subspecialty of vascular surgery named endovascular surgery that may be performed by the vascular surgeon, and that lasts for a year. Typically, after concluding the second year, the new vascular surgeons participate in this residency program (R3). Surgeries are divided in small size, medium size, and large size surgeries (Table 4).

Despite the validity of the division as a normative instrument, the chief surgeon of vascular surgery categorizes surgeries of this specialty in seven aggregated groups: varicose veins and veins surgeries, aorta surgeries, fistula surgeries, femoral surgeries, carotid surgeries, amputation surgeries, and endovascular procedures.

Table 4. Minimum amount of procedures defined by the current legislation.

\begin{tabular}{|c|c|c|}
\hline $\begin{array}{l}\text { CNRM Resolution number } \\
02 / 2006\end{array}$ & \multicolumn{2}{|c|}{$\begin{array}{c}\text { Minimum amount of procedures to be performed by the professional to obtain the license to offer } \\
\text { vascular surgery service }\end{array}$} \\
\hline $\begin{array}{l}\text { Classification of vascular } \\
\text { surgery procedures }\end{array}$ & Procedures & $\begin{array}{l}\text { Amount of surgeries } \\
\text { throughout the year }\end{array}$ \\
\hline Small size & $\begin{array}{l}\text { Vascular accesses, arteriovenous fistulas, vascular radiology, small } \\
\text { amputations and debridement }\end{array}$ & 45 \\
\hline Medium size & $\begin{array}{l}\text { Embolectomies; femoral-popliteal, femoral-femoral, axillo-femoral, } \\
\text { iliac-femoral, distal grafts; venous surgeries; amputations, sympathectomies } \\
\text { and vascular radiology. }\end{array}$ & 60 \\
\hline Large size & $\begin{array}{l}\text { Surgery of the carotid arteries, aneurysms, aortoiliac and femoral grafts, } \\
\text { arterial reoperations }\end{array}$ & 45 \\
\hline Total & - & 150 \\
\hline
\end{tabular}

Source: adapted from the Ministery of Education (Brasil, 2006).

This additional categorization brought the necessity to build Table 5 together with the surgeon chief of vascular surgery to draw the intersection between these surgery groups and the procedures described by the normative instrument regarding "size" and group. On the second to last column, arterial surgeries are assigned with an X. This emphasizes the importance of the development of decision support models in collaboration with their future users. On the last line, the number of surgeries by size are established, following the same proportion established by the CNRM Resolution Number 02/2006 (Brasil, 2006).

Through Table 5 , it is possible to notice that a resident may reach the minimum number of surgeries by size established by the CNRM Resolution by executing many procedures in more than one category throughout the year. Despite this, the professors (preceptors) of vascular surgery (staff) understand that a less experienced resident should execute and improve their ability in more simple procedures, while more experienced ones should improve their ability in procedures of higher complexity. This relation is presented in Table 6 , where X indicates which resources are necessary to execute each type of surgery. On the columns R1 Doctor, R2 Doctor, and R3 Doctor, the $\mathrm{X}$ indicates that this resident doctor is enabled to execute that type of procedure. However, only one resident doctor is allocated to perform each surgery. As in the case of Table 5, Table 6 was also built together with the chief surgeon of vascular surgery. The chief surgeon also indicated that the R3 resident doctor doesn't perform amputation surgeries, even though he/she is enabled to do amputations of any size.

This research considers that the sterile processing department (Central de Material de Esterilização - CME) cannot sterilize the surgical instruments for reuse on the same day; that is, thoughout the day, the CME only stores the surgical instruments. The stock levels of each type of surgical instruments are described on Table 7. 1t is also assumed that the hospital's blood bank has the capacity to provide blood bags for up to 1 patient per day. 
Table 5. Classification of procedures regarding category and size.

\begin{tabular}{|c|c|c|c|c|}
\hline Surgery size & $\begin{array}{l}\text { Great categories - } \\
\text { classification per blocks of } \\
\text { surgery }\end{array}$ & Procedures & Arterial surgeries & $\begin{array}{c}\text { Number of surgeries } \\
\text { per year (CNRM } \\
\text { Resolution number } \\
02 / 2006 \text { ) }\end{array}$ \\
\hline \multirow[t]{7}{*}{ Small } & Varicose veins and veins & Venous surgeries & & - \\
\hline & Aorta & - & $x$ & \\
\hline & Fistula & Vascular access & $x$ & \\
\hline & Femoral & - & $x$ & \\
\hline & Carotid & - & $x$ & \\
\hline & Amputation & Amputation & & \\
\hline & Endovascular & Vascular radiology & & \\
\hline Subtotal & Small size & - & - & 15 \\
\hline \multirow[t]{7}{*}{ Medium } & Varicose veins and veins & Venous surgeries & & - \\
\hline & Aorta & - & $\mathrm{x}$ & \\
\hline & Fistula & Vascular access & $x$ & \\
\hline & Femoral & $\begin{array}{l}\text { Femoral-popliteal, femoral-femoral, } \\
\text { axillo-femoral, iliac-femoral, distal } \\
\text { grafts }\end{array}$ & $x$ & \\
\hline & Carotid & axillo-femoral & $x$ & \\
\hline & Amputation & Amputation & & \\
\hline & Endovascular & Vascular radiology & & \\
\hline Subtotal & Medium size & & & 20 \\
\hline \multirow[t]{7}{*}{ Large } & Varicose veins and veins & Venous surgeries & & - \\
\hline & Aorta & $\begin{array}{l}\text { Axillo-femoral, surgery of the carotid } \\
\text { arteries, aneurysms, aortoiliac and } \\
\text { femoral grafts, arterial reoperations }\end{array}$ & & \\
\hline & Fistula & Vascular access & $\mathrm{x}$ & \\
\hline & Femoral & $\begin{array}{l}\text { Axillo-femoral, surgery of the carotid } \\
\text { arteries, aneurysms, aortoiliac and } \\
\text { femoral grafts, arterial reoperations }\end{array}$ & $x$ & \\
\hline & Carotid & $\begin{array}{l}\text { Axillo-femoral, surgery of the carotid } \\
\text { arteries, aneurysms, aortoiliac and } \\
\text { femoral grafts, arterial reoperations }\end{array}$ & $x$ & \\
\hline & Amputation & Amputation & & \\
\hline & Endovascular & Vascular radiology & & \\
\hline Subtotal & Large size & - & - & 15 \\
\hline Total & - & - & - & 50 \\
\hline
\end{tabular}

Source: Chief of vascular surgery service and Ministry of Education (Brasil, 2006).

The relation between the amount of residents by type (R1 doctor, $\mathrm{R} 2$ doctor, and R3 doctor) and the minimum frequency in which they should be allocated is presented in Table 8

The operating hours of the operating room, to meet the demand for elective surgeries, are from 7 am to $7 \mathrm{pm}$, on weekdays only. However, working hours were considered to be from 8 am to $5 \mathrm{pm}$ ( 540 minutes) in order to ensure 25\% of slack time (the current literature assumes slack time between 20 and 30 percent of total time) (M'Hallah \& Al-Roomi, 2014). It is also assumed that the time horizon (one year) in working days is 250 days.

\section{Nomenclature and mathematical problem formulation: a surgery planning and scheduling}

Proposing a surgery plan and a surgery schedule that respect all rules imposed by the legislation and by the hospital is a difficult and time-consuming task. This task is currently performed manually by the chief surgeon.

This article proposes a mathematical model to increase the efficiency of surgical planning. In other words, the model has the objective of finding the configuration that minimizes resource allocation (rooms, anesthetists and equipment), while respecting the minimum amount of surgeries. In addition, the proposed model considers as business rules: the minimum frequency of scheduling of the group of residents per week; the maximum amount of rooms available in the week; the maximum number of anesthetists available in the week; and the maximum amount of equipment available in the week. 
Table 6 . Relation between types of surgery and necessary inputs.

\begin{tabular}{|c|c|c|c|c|c|c|c|c|c|c|c|c|c|c|c|c|c|c|c|c|}
\hline \multicolumn{2}{|c|}{ Resource parametrization } & \multicolumn{9}{|c|}{ Necessary resources } & \multicolumn{4}{|c|}{ Time (in minutes) } & \multicolumn{3}{|c|}{$\begin{array}{l}\text { Human } \\
\text { Resources }\end{array}$} & \multicolumn{3}{|c|}{$\begin{array}{l}\text { Minimum } \\
\text { amount of } \\
\text { surgeries }\end{array}$} \\
\hline Surgery size & $\begin{array}{l}\text { Great categories - } \\
\text { classification per blocks of } \\
\text { vascular surgery }\end{array}$ & $\begin{array}{l}\frac{\bar{a}}{0} \\
\frac{\pi}{0} \\
\frac{0}{0} \\
\frac{1}{0} \\
\frac{0}{0} \\
\frac{0}{2}\end{array}$ & 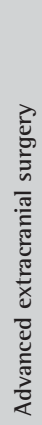 & 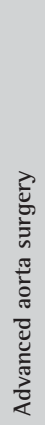 & 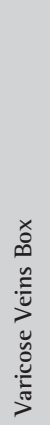 & 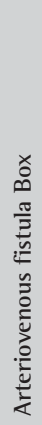 & 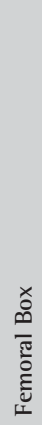 & 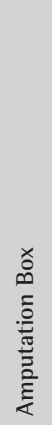 & 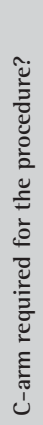 & 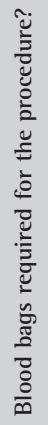 & 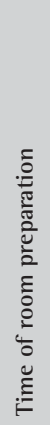 & 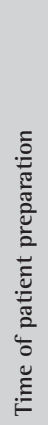 & 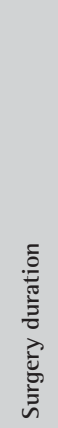 & 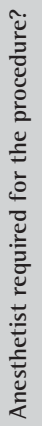 & 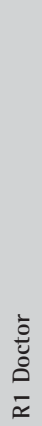 & 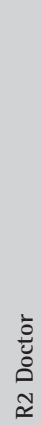 & 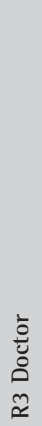 & 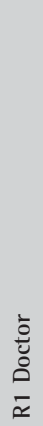 & $\begin{array}{l}\grave{o} \\
\stackrel{0}{0} \\
\stackrel{0}{\simeq} \\
\tilde{D}\end{array}$ & 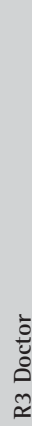 \\
\hline \multirow[t]{7}{*}{ Small } & Varicose veins and veins & $\mathrm{x}$ & & & $\mathrm{x}$ & & & & & & 20 & 0 & 45 & - & $\mathrm{x}$ & $x$ & $\mathrm{x}$ & 10 & 0 & 0 \\
\hline & Aorta & & & $x$ & & & & & $X$ & $x$ & 20 & 0 & - & - & & $x$ & $x$ & 0 & 0 & 0 \\
\hline & Fistula & & & & & $\mathrm{x}$ & & & & & 20 & 0 & 60 & - & $\mathrm{x}$ & $\mathrm{x}$ & $\mathrm{x}$ & 20 & 0 & 0 \\
\hline & Femoral & $\mathrm{x}$ & & & & & $\mathrm{x}$ & & $\mathrm{x}$ & $\mathrm{x}$ & 20 & 0 & 150 & $x$ & $x$ & $x$ & $x$ & 5 & 15 & 0 \\
\hline & Carotid & & $\mathrm{x}$ & & & & & & $x$ & & 20 & 0 & - & - & & $x$ & $x$ & 0 & 0 & 0 \\
\hline & Amputation & & & & & & & $\mathrm{x}$ & & & 20 & 0 & 40 & - & $\mathrm{x}$ & $x$ & $x$ & 10 & 0 & 0 \\
\hline & Endovascular (Laparoscopy) & & & & & $\mathrm{x}$ & $\mathrm{x}$ & & $\mathrm{x}$ & & 20 & 0 & 60 & - & & $x$ & $x$ & 0 & 10 & 15 \\
\hline \multirow[t]{7}{*}{ Medium } & Varicose veins and veins & $X$ & & & $\mathrm{X}$ & & & & & & 20 & 20 & 75 & $\mathrm{x}$ & $\mathrm{x}$ & $\mathrm{x}$ & $\mathrm{x}$ & 10 & 5 & 0 \\
\hline & Aorta & & & $x$ & & & & & $\mathrm{x}$ & $x$ & 20 & 20 & - & - & & $\mathrm{x}$ & $x$ & 0 & 0 & 0 \\
\hline & Fistula & & & & & $\mathrm{x}$ & & & & & 20 & 20 & 110 & $\mathrm{x}$ & $\mathrm{x}$ & $x$ & $\mathrm{x}$ & 20 & 0 & 0 \\
\hline & Femoral & $x$ & & & & & $x$ & & $\mathrm{x}$ & $x$ & 20 & 20 & 210 & $\mathrm{x}$ & $x$ & $\mathrm{x}$ & $\mathrm{x}$ & 10 & 15 & 15 \\
\hline & Carotid & & $\mathrm{x}$ & & & & & & $x$ & & 20 & 20 & 135 & $x$ & & $x$ & $x$ & 0 & 15 & 10 \\
\hline & Amputation & & & & & & & $\mathrm{x}$ & & & 20 & 20 & 50 & $x$ & $\mathrm{x}$ & $x$ & $x$ & 10 & 0 & 0 \\
\hline & Endovascular (Laparoscopy) & & & & & $\mathrm{x}$ & $\mathrm{x}$ & & $\mathrm{x}$ & & 20 & 20 & 135 & - & & $\mathrm{x}$ & $\mathrm{x}$ & 0 & 10 & 20 \\
\hline \multirow[t]{7}{*}{ Large } & Varicose veins and veins & $\mathrm{x}$ & & & $\mathrm{x}$ & & & & & & 20 & 90 & 105 & $x$ & $x$ & $x$ & $x$ & 5 & 5 & 0 \\
\hline & Aorta & & & $\mathrm{x}$ & & & & & $\mathrm{x}$ & $\mathrm{x}$ & 20 & 90 & 240 & $\mathrm{x}$ & & $x$ & $x$ & 0 & 15 & 5 \\
\hline & Fistula & & & & & $\mathrm{x}$ & & & & & 20 & 90 & 110 & $x$ & $x$ & $x$ & $x$ & 5 & 5 & 0 \\
\hline & Femoral & $X$ & & & & & $x$ & & $x$ & $x$ & 20 & 90 & 210 & $\mathrm{X}$ & $x$ & $x$ & $x$ & 5 & 10 & 5 \\
\hline & Carotid & & $\mathrm{x}$ & & & & & & $x$ & & 20 & 90 & 135 & $\mathrm{X}$ & & $x$ & $x$ & 0 & 5 & 10 \\
\hline & Amputation & & & & & & & $\mathrm{x}$ & & & 20 & 90 & 90 & $x$ & $\mathrm{x}$ & $x$ & $x$ & 5 & 5 & 0 \\
\hline & Endovascular (Laparoscopy) & & & & & $\mathrm{x}$ & $\mathrm{x}$ & & $\mathrm{x}$ & & 20 & 90 & 165 & $\mathrm{x}$ & & & $\mathrm{x}$ & 0 & 0 & 10 \\
\hline
\end{tabular}

Source: chief of vascular surgery service.

Table 7. Amount of surgery instruments available at the CME.

\begin{tabular}{lc}
\hline \multicolumn{1}{c}{ CME - Surgery instruments } & Amount available at CME \\
\hline Phlebo-extractor & 1 \\
Advanced extracranial surgery & 2 \\
Advanced aorta surgery & 2 \\
Varicose Veins Box & 5 \\
FAV Box & 2 \\
Femoral Box & 3 \\
Amputation Box & 2 \\
\hline
\end{tabular}

Table 8. Number of residentes by type.

\begin{tabular}{ccc}
\hline Type of resident & Number of residents & $\begin{array}{c}\text { Minimum frequency of } \\
\text { weekly allocation }\end{array}$ \\
\hline R1 Doctor & 2 & 3 \\
R2 Doctor & 2 & 3 \\
R3 Doctor & 2 & 3 \\
\hline
\end{tabular}


The nomenclature and mathematical model formulation are presented in Tables 9, 10 and 11 . The model was implemented in the commercial software AIMMS 3.14 with the standard solver CPLEX 12.6 (Bisschop \& Roelofs, 2011) on a computer with Intel Core i5 and $16 \mathrm{~Gb}$ of RAM.

Table 9. Statement of Master Surgical Schedule model indexes.

\begin{tabular}{cllc}
\hline Indexes & \multicolumn{1}{c}{ Meaning } & \multicolumn{1}{c}{ Domain } & Sub indexes \\
\hline ar & arterial surgery & $\mathrm{AR}=[2: 5]$ & \\
$\mathrm{S}$ & Surgery & $\mathrm{C}=[1: 7]$ & \\
$\mathrm{d}$ & Day & $\mathrm{D}=[1: 250]$ & ar \\
$\mathrm{e}$ & Equipment & $\mathrm{E}=[1: 1]$ & \\
$\mathrm{i}$ & Resource & $\mathrm{R}=[1: 3]$ & \\
$\mathrm{m}$ & Material & $\mathrm{M}=[1: 7]$ & \\
z & Surgery size & $\mathrm{P}=[1: 3]$ & $\mathrm{s}, \mathrm{e}$ \\
$\mathrm{C}$ & Class (group) of residents & $\mathrm{R}=[1: 3]$ & \\
$\mathrm{r}$ & Room & $\mathrm{S}=[1: 2]$ & \\
\hline
\end{tabular}

Table 10. Statement of Master Surgical Schedule model variables.

\begin{tabular}{|c|c|c|}
\hline Variables & Meaning and type & Type \\
\hline $\mathrm{AcClSu}_{\mathrm{c}, \mathrm{s}, \mathrm{z}}$ & Number of surgeries (s) of size (z) performed by residents of type (c) in the year & Integer \\
\hline $\mathrm{AnSu}_{\mathrm{s}, \mathrm{z}}^{\mathrm{r}, \mathrm{d}}$ & Decision of allocating an anesthetist to perform surgery (s) of size (z) in room (r) on day (d) & Binary \\
\hline AnDay ${ }^{\mathrm{r}, \mathrm{d}}$ & Decision of allocating an anesthetist in room (r) on day (d) & Binary \\
\hline $\operatorname{AuxAn}{ }^{r, d}$ & Auxiliary variable created to associate variables $\mathrm{AnSu}_{\mathrm{s}, 1}^{\mathrm{r}, \mathrm{d}}$ and $\mathrm{AnDay}$, d & Integer \\
\hline $\operatorname{AuxEq} q_{\mathrm{e}}^{\mathrm{r}, \mathrm{d}}$ & Auxiliary variable created to associate variables $\mathrm{EqSu}_{\mathrm{e}, \mathrm{s}, 1}^{\mathrm{r}, \mathrm{d}}$ and $\mathrm{EqDay}_{\mathrm{e}}^{\mathrm{r}, \mathrm{d}}$ & Integer \\
\hline $\mathrm{AuxCl}_{\mathrm{r}}^{\mathrm{d}}$ & Auxiliary variable created to associate variables $\mathrm{ClSu}_{\mathrm{c}, \mathrm{s}, 1}^{\mathrm{r}, \mathrm{d}}$ and $\mathrm{ClDay} \mathrm{r}_{\mathrm{r}}^{\mathrm{d}}$ & Integer \\
\hline $\mathrm{EqSu}_{\mathrm{e}, \mathrm{s}, \mathrm{z}}^{\mathrm{r}, \mathrm{d}}$ & Decision of allocating equipment (e) in surgery (s) of size (z) in room (r) on day (d) & Binary \\
\hline EqDay $_{\mathrm{e}}^{\mathrm{r}, \mathrm{d}}$ & Decision of allocating equipment (e) in room (r) on day (d) & Binary \\
\hline $\mathrm{MatSu}_{\mathrm{m}, \mathrm{s}, \mathrm{z}}^{\mathrm{r}, \mathrm{d}}$ & Decision of allocating surgical material $(\mathrm{m})$ in surgery $(\mathrm{s})$ of size $(\mathrm{z})$ in room $(\mathrm{r})$ on day $(\mathrm{d})$ & Binary \\
\hline $\mathrm{ClSu}_{\mathrm{c}, \mathrm{s}, \mathrm{z}}^{\mathrm{r}, \mathrm{d}}$ & Decision of allocating a resident of type (c) to perform surgery (s) of size $(\mathrm{z})$ in room (r) on day (d) & Binary \\
\hline ClDay $_{\mathrm{r}}^{\mathrm{d}}$ & Decision of allocating any resident of type (r) on day (d) & Binary \\
\hline $\operatorname{Room}^{\mathrm{r}, \mathrm{d}}$ & Decision of allocating or blocking room (r) on day (d) for the surgical service & Binary \\
\hline BloodSu $\mathrm{s}, \mathrm{z}_{\mathrm{r}}^{\mathrm{r}, \mathrm{d}}$ & Decision of allocating blood bag in surgery (s) of size (z) in room (r) on day (d) & Binary \\
\hline
\end{tabular}

Table 11. Statement of Master Surgical Schedule model parameters.

\begin{tabular}{|c|c|c|}
\hline Parameters & Meaning & Values \\
\hline $\operatorname{durSu}_{\mathrm{s}, \mathrm{z}}$ & Duration of surgery (s) of size (z) & Table 6 \\
\hline$\underline{\text { fClwk }}$ & Minimum frequency of groups of residents per week & Table 12 \\
\hline $\mathrm{haClSu}_{\mathrm{s}, \mathrm{r}, \mathrm{z}}$ & Resident's (c) habilitation to perform surgery (s) of size (z) & Table 6 \\
\hline M & Large number & 100.000 \\
\hline weight $_{\mathrm{i}}$ & Weight assigned to each type of resource (i) & Table 12 \\
\hline$\overline{\text { nAnwk }}$ & Maximum number of anesthetists available in the week & Table 12 \\
\hline$\underline{\mathrm{nSuYr}}$ & Minimum number of surgeries year for each resident & Table 4 \\
\hline$\underline{\mathrm{nSuAr}}$ & Minimum number of arterial surgeries for each resident & Table 5 \\
\hline$\underline{\mathrm{nSuArSz}}_{\mathrm{z}}$ & Minimum number of arterial surgeries per size for each resident & Table 5 \\
\hline$\underline{\mathrm{nSuSz}}_{\mathrm{z}}$ & Minimum number of surgeries of size for each resident & Table 4 \\
\hline$\underline{\mathrm{nSuCl}}_{\mathrm{c}, \mathrm{s}, \mathrm{p}}$ & Minimum number of surgeries (s) of size (z) for resident of type (c) established by the preceptor & Table 6 \\
\hline
\end{tabular}


Table 11. Continued...

\begin{tabular}{|c|c|c|}
\hline Parameters & Meaning & Values \\
\hline$\overline{\mathrm{nEqwk}}_{\mathrm{e}}$ & Maximum number of equipment (e) assigned in the week & Table 12 \\
\hline $\mathrm{nMat}_{\mathrm{m}}$ & Number of surgical materials $(\mathrm{m})$ available at SMC & Table 7 \\
\hline $\mathrm{nCl}_{\mathrm{c}}$ & Number of residents per type (c) & Table 8 \\
\hline$\overline{\text { nroomwk }}$ & Maximum amount of rooms assigned in the week & Table 12 \\
\hline nblood & Number of patients attended by hemotherapy service (blood) per day & 1 \\
\hline $\mathrm{rSuAn}_{\mathrm{s}, \mathrm{z}}$ & Anesthetist-surgery relation $(\mathrm{s}, \mathrm{z})$ & Table 6 \\
\hline $\mathrm{rSuEq}_{\mathrm{s}, \mathrm{z}, \mathrm{e}}$ & Surgery-equipment relation $(\mathrm{s}, \mathrm{z}, \mathrm{e})$ & Table 6 \\
\hline $\mathrm{rSuMat}_{\mathrm{s}, \mathrm{z}, \mathrm{m}}$ & Surgery-material relation $(\mathrm{s}, \mathrm{z}, \mathrm{m})$ & Table 6 \\
\hline $\operatorname{rSublood}_{\mathrm{s}, \mathrm{z}}$ & Surgery-blood relation $(\mathrm{s}, \mathrm{z})$ & Table 6 \\
\hline tPrep $_{z}$ & Preparation time for surgery of size $(\mathrm{z})$ & Table 6 \\
\hline tPreroom & Room preparation time & Table 6 \\
\hline troom & Room time & 540 minutes \\
\hline
\end{tabular}

Objective function:

Min $\sum_{\mathrm{e}, \mathrm{r}, \mathrm{d}}$ Weight $_{1} *$ Room $^{\mathrm{r}, \mathrm{d}}+\mathrm{Weight}_{2} * \mathrm{AnDay}^{\mathrm{r}, \mathrm{d}}+\mathrm{Weight}_{3} * \mathrm{EqDay}_{\mathrm{e}}^{\mathrm{r}, \mathrm{d}}$

The objective function (1) minimizes the room allocation $\left(\operatorname{Room}^{r, d}\right)$, anesthetists $\left(A n D a y^{r, d}\right)$ and equipment $\left(E q D a y_{e}^{r, d}\right)$ throughout the year. Prioritization is defined by the weights $\left(\right.$ Weight $\left._{i}\right)$. For example, if the weight assigned to the resource room is greater than the weights assigned to the other ones, the solver will seek the lowest possible room allocation value that meets all the constraints that will be presented below.

Constraints:

$$
\begin{aligned}
& \sum_{\mathrm{s}, \mathrm{z}, \mathrm{c}} \mathrm{ClSu}_{\mathrm{c}, \mathrm{s}, \mathrm{z}}^{\mathrm{r}, \mathrm{d}} *\left(\mathrm{durSu}_{\mathrm{s}, \mathrm{z}}+\operatorname{tPrep}_{\mathrm{z}}+\text { tPreproom }\right) \leq \text { troom } \forall \mathrm{r}, \mathrm{d} \\
& \sum_{\mathrm{s}, \mathrm{z}, \mathrm{r}} \mathrm{ClSu}_{\mathrm{c}, \mathrm{s}, \mathrm{z}}^{\mathrm{r}, \mathrm{d}} *\left(\mathrm{durSu}_{\mathrm{s}, \mathrm{z}}+\mathrm{tPrep}_{\mathrm{z}}+\text { tPres }\right) \leq \text { troom } \forall \mathrm{c}, \mathrm{d} \\
& \mathrm{ClSu}_{\mathrm{c}, \mathrm{s}, \mathrm{z}}^{\mathrm{r}, \mathrm{d}} \leq \mathrm{Room}^{\mathrm{r}, \mathrm{d}} \forall \mathrm{c}, \mathrm{s}, \mathrm{z}, \mathrm{r}, \mathrm{d} \\
& \mathrm{AClSu}_{\mathrm{c}, \mathrm{s}, \mathrm{z}}=\sum_{\mathrm{r}, \mathrm{d}} \mathrm{ClSu}_{\mathrm{c}, \mathrm{s}, \mathrm{z}}^{\mathrm{r}, \mathrm{d}} \forall \mathrm{c}, \mathrm{s}, \mathrm{z} \\
& \mathrm{AClSu}_{\mathrm{c}, \mathrm{s}, \mathrm{z}} \geq \underline{\mathrm{nSuCl}}_{\mathrm{c}, \mathrm{s}, \mathrm{z}} * \mathrm{nCl}_{\mathrm{c}} \quad \forall \mathrm{c}, \mathrm{s}, \mathrm{z} \\
& \sum_{\mathrm{s}} \mathrm{AClSu}_{\mathrm{c}, \mathrm{s}, \mathrm{z}} \geq \underline{\mathrm{nSuSz}}_{\mathrm{z}} * \mathrm{nCl}_{\mathrm{c}} \quad \forall \mathrm{c}, \mathrm{z} \\
& \sum_{\mathrm{ar}, 1} \mathrm{AClSu}_{\mathrm{c}, \mathrm{ar}, \mathrm{z}} \geq \underline{\mathrm{nSuAr}^{*}} * \mathrm{nCl}_{\mathrm{c}} \forall \mathrm{c} \\
& \sum_{\mathrm{ar}} \mathrm{AClSu}_{\mathrm{c}, \mathrm{ar}, \mathrm{z}} \geq \underline{\mathrm{nSuArSz}}_{\mathrm{z}} * \mathrm{nCl}_{\mathrm{c}} \quad \forall \mathrm{c}, \mathrm{z} \\
& \sum_{\mathrm{s}, \mathrm{z}} \mathrm{AClSu}_{\mathrm{c}, \mathrm{s}, \mathrm{z}} \geq \underline{\mathrm{nSuyr}^{*}} * \mathrm{nCl}_{\mathrm{c}} \forall \mathrm{c} \\
& \mathrm{AnSu}_{\mathrm{s}, \mathrm{z}}^{\mathrm{r}, \mathrm{d}}=\sum_{\mathrm{c}} \mathrm{ClSu}_{\mathrm{c}, \mathrm{s}, \mathrm{z}}^{\mathrm{r}, \mathrm{d}} \forall \mathrm{s}, \mathrm{z}, \mathrm{r}, \mathrm{d}
\end{aligned}
$$




$$
\begin{aligned}
& \operatorname{AnDay}^{\mathrm{r}, \mathrm{d}}+\operatorname{AuxAn}^{\mathrm{r}, \mathrm{d}}=\sum_{\mathrm{s}, \mathrm{z}} \mathrm{AnSu}_{\mathrm{s}, \mathrm{z}}^{\mathrm{r}, \mathrm{d}} \forall \mathrm{r}, \mathrm{d} \\
& \text { AnDay }^{\mathrm{r}, \mathrm{d}} * \mathrm{M} \geq \sum_{\mathrm{s}, \mathrm{z}} \mathrm{AnSu}_{\mathrm{s}, \mathrm{z}}^{\mathrm{r}, \mathrm{d}} \forall \mathrm{r}, \mathrm{d} \\
& \mathrm{EqDay}_{\mathrm{e}}^{\mathrm{r}, \mathrm{d}}+\mathrm{AuxEq}_{\mathrm{e}}^{\mathrm{r}, \mathrm{d}}=\sum_{\mathrm{s}, \mathrm{z}} \mathrm{EqSu}_{\mathrm{e}, \mathrm{c}, \mathrm{p}}^{\mathrm{r}, \mathrm{d}} \forall \mathrm{e}, \mathrm{r}, \mathrm{d} \\
& \text { EqDay }_{\mathrm{e}}^{\mathrm{s}, \mathrm{d}} * \mathrm{M} \geq \sum_{\mathrm{s}, \mathrm{z}} \mathrm{EqSu}_{\mathrm{e}, \mathrm{s}, \mathrm{z}}^{\mathrm{r}, \mathrm{d}} \forall \mathrm{e}, \mathrm{r}, \mathrm{d} \\
& \mathrm{ClDay}_{\mathrm{c}}^{\mathrm{d}}+\operatorname{AuxCl}_{\mathrm{c}}^{\mathrm{d}}=\sum_{\mathrm{s}, \mathrm{z}, \mathrm{r}} \mathrm{ClSu}_{\mathrm{c}, \mathrm{s}, \mathrm{z}}^{\mathrm{r}, \mathrm{d}} \forall \mathrm{c}, \mathrm{d} \\
& \mathrm{ClDay}_{\mathrm{c}}^{\mathrm{d}} * \mathrm{M} \geq \sum_{\mathrm{s}, \mathrm{z}, \mathrm{r}} \mathrm{ClSu}_{\mathrm{c}, \mathrm{s}, \mathrm{z}}^{\mathrm{r}, \mathrm{d}} \forall \mathrm{c}, \mathrm{d} \\
& \operatorname{MatSu}_{\mathrm{m}, \mathrm{s}, \mathrm{z}}^{\mathrm{r}, \mathrm{d}}=\sum_{\mathrm{c}} \mathrm{ClSu}_{\mathrm{s}, \mathrm{c}, \mathrm{p}}^{\mathrm{r}, \mathrm{d}} \forall \mathrm{m}, \mathrm{s}, \mathrm{z}, \mathrm{r}, \mathrm{d} \\
& \sum_{\mathrm{s}, \mathrm{z}, \mathrm{r}} \mathrm{MatSu}_{\mathrm{m}, \mathrm{s}, \mathrm{z}}^{\mathrm{r}, \mathrm{d}} \leq \mathrm{nMat}_{\mathrm{m}} \forall \mathrm{m}, \mathrm{d} \\
& \operatorname{BloodSu}_{\mathrm{s}, \mathrm{z}}^{\mathrm{r}, \mathrm{d}}=\sum_{\mathrm{c}} \mathrm{ClSu}_{\mathrm{s}, \mathrm{c}, \mathrm{p}}^{\mathrm{r}, \mathrm{d}} \forall \mathrm{s}, \mathrm{z}, \mathrm{r}, \mathrm{d} \\
& \sum_{\mathrm{s}, \mathrm{z}, \mathrm{r}} \operatorname{BloodSu}_{\mathrm{s}, \mathrm{z}}^{\mathrm{r}, \mathrm{d}} \leq \mathrm{nBlood} \forall \mathrm{d} \\
& \sum_{\mathrm{d}-4}^{\mathrm{d}} \text { ClDay }_{\mathrm{c}}^{\mathrm{d}} \geq \underline{\text { fClwk }} \forall \mathrm{c}, \mathrm{d} \\
& \sum_{\mathrm{r}, \mathrm{d}-4}^{\mathrm{d}} \text { Room }^{\mathrm{r}, \mathrm{d}} \leq \overline{\text { nRoomwk }} \forall \mathrm{d} \\
& \sum_{\mathrm{r}, \mathrm{d}-4}^{\mathrm{d}} \mathrm{AnSu}^{\mathrm{r}, \mathrm{d}} \leq \overline{\mathrm{nAnwk}} \forall \mathrm{d} \\
& \sum_{\mathrm{r}, \mathrm{d}-4}^{\mathrm{d}} \operatorname{EqDay}_{\mathrm{e}}^{\mathrm{r}, \mathrm{d}} \leq \overline{\mathrm{nEqwk}}_{\mathrm{e}} \forall \mathrm{e}, \mathrm{d}
\end{aligned}
$$

Equation 2 ensures that each room is used in the operating hours of the surgery room (not allowing overtime) and Equation 3 ensures that each resident works until the limit of the working hours of the surgery room (not allowing overtime). The combination of Equations 2 and 3 prevents each resident from having workloads that are incompatible with the available room time by adding all the available rooms, what would mean, in practice, to allocate the professional in two rooms at the same time.

Equation 4 just allows any resident of type (c) to be allocated to perform the surgery (s) of size (z) in the room ( $r$ ) and day (d) in case this room (r) is available for the surgery service on day (d). In order to increase the model's efficiency (reduce resolution and interactions time), this constraint is only created when $\mathrm{durSu}_{\mathrm{s}, \mathrm{z}}>0$ and $\mathrm{hClSu}_{\mathrm{c}, \mathrm{s}, \mathrm{z}}=1$, in other words, when the surgery (s) of size (z) exists and when the resident of type (c) is able to perform it.

Equation 5 accumulates the quantity of each surgery (s) of size (z) performed by the resident of type (c) and is created when durSu $u_{s, z}>0$ and haClSu $u_{c, s, z}=1$ following the same logic of the previous equation. The variable $\mathrm{AClSu}_{\mathrm{c}, \mathrm{s}, \mathrm{z}}$ is used in Equations 6, 7, 8 and 9 to ensure the minimum quantity of the surgeries.

This model doesn't allocate the surgeon to the surgery, but rather designates the group of surgeons (in this case, R1, R2, or R3) who will perform it. Thus, it's necessary, in Equations 6 to 10, to multiply the number of surgeries by the number of surgeons of that group. 
Equation 11 associates, for each surgery (s) of size (z), the necessity of an anesthetist. It is created when $\operatorname{durSu}_{\mathrm{s}, \mathrm{z}}>0$ and $\mathrm{rSuAn}_{\mathrm{s}, \mathrm{z}}=1$, in other words, when the surgery (s) of size (z) exists and when it needs an anesthetist.

Equations 12 and 13 associate the daily and per-room allocation of the anesthetist (variable AnDay ${ }^{\mathrm{r}, \mathrm{d}}$ ) to the quantity of surgeries performed with an anesthetist for each surgery $\left(\sum \mathrm{AnSu}_{\mathrm{s}, \mathrm{z}}^{\mathrm{r}, \mathrm{d}}\right)$ and that are necessary to meet the term $\sum_{\mathrm{r}, \mathrm{d}}$ Weight $_{2}{ }^{*}$ AnDay $^{\mathrm{r}, \mathrm{d}}$ of the objective function. Since the decision to allocate some anesthetists to the room (r) and day (d) is binary (AnDay ${ }^{\mathrm{r}, \mathrm{d}}$ ), it was necessary to create an auxiliary variable AuxAn ${ }^{\mathrm{r}, \mathrm{d}}$ in Equation 11 to receive the difference between the quantity of surgeries and the binary variable. However, it's necessary for this allocative decision to be equal to 1 every time an anesthetist is assigned to a room while, at the same time, one is trying to minimize $\sum$ Weight $_{2}{ }^{*}$ AnDay $^{\mathrm{r}, \mathrm{d}}$. In order to solve this problem, one multiplies the binary decision variable by a large number (M), which, by its turn, must be greater than the right side of the equation. This method ensures that whenever the quantity of surgeries in a day and in a room is greater than 1 , the decision variable will receive the value 1 .

Equations 14 and 15 associate the daily and room allocation of the resource equipment (variable EqDayer, to the number of surgeries performed with equipment for each surgery $\left(\mathrm{EqSS}_{\mathrm{e}, \mathrm{s}, \mathrm{z}}^{\mathrm{r}, \mathrm{d}}\right)$ and that are necessary to meet the term $\sum_{\mathrm{e}, \mathrm{r}, \mathrm{d}}$ Weight $_{3}{ }^{*} \mathrm{EqDay}_{\mathrm{e}}^{\mathrm{r}, \mathrm{d}}$ of the objective function. The terms $\mathrm{EqDay}_{\mathrm{e}}^{\mathrm{r}, \mathrm{d}}, \mathrm{AuxEq}_{\mathrm{e}}^{\mathrm{r}, \mathrm{d}}, \mathrm{EqSu}_{\mathrm{e}, \mathrm{s}, \mathrm{z}}^{\mathrm{r}, \mathrm{d}}$, and $\mathrm{M}$ follow the same logic presented in the explanation of Equations 11 and 12.

Equations 16 and 17 associate the allocation of resident of type ( $r$ ) on day (d) (variable CIDay ${ }_{c}^{d}$ ) and are necessary to meet Equation 21, which refers to the minimum frequency of resident scheduling per week. The terms $\mathrm{ClDay}_{\mathrm{c}}^{\mathrm{d}}, \mathrm{AuxCl}_{\mathrm{c}}^{\mathrm{d}}, \mathrm{ClSu}_{\mathrm{c}, \mathrm{s}, \mathrm{l}}^{\mathrm{r}, \mathrm{d}}$, and $\mathrm{M}$ follow the same logic presented in the explanation of Equations 11 and 12 .

Equation 18 associates the surgical material ( $\mathrm{MatSu}_{\mathrm{m}, \mathrm{s}, \mathrm{z}}^{\mathrm{r}, \mathrm{d}}$ ) necessary for each surgery (s) of size (z). It is created when durSu $\mathrm{s}_{\mathrm{s}, \mathrm{l}}>0$ and $\mathrm{rSuMat}_{\mathrm{s}, \mathrm{z}, \mathrm{m}}=1$, in other words, when the surgery ( $\mathrm{s}$ ) of size (z) exists and when surgical material $(\mathrm{m})$ is required. Equation 19 limits the quantitative of surgeries performed in the day (d) due to the availability of surgical materials $(\mathrm{m})$.

Equation 20 associates the blood bag $\left(\mathrm{SanCi}_{\mathrm{s}, \mathrm{d}, \mathrm{d}}\right)$ necessary for each surgery $(\mathrm{s})$ of size $(\mathrm{z})$. It is created when $\operatorname{durSur}_{\mathrm{s}, \mathrm{z}}>0$ and $\operatorname{rSuBlood}_{\mathrm{s}, \mathrm{z}}=1$, in other words, when the surgery (s) of of size (z) exists, and when blood bags are necessary.

Equation 21 limits the number of surgeries performed in the day (d) depending on the availability of blood bags made available by the hemotherapy service.

Equation 22 ensures, for any 5 consecutive days (week), that the group of residents ( $r$ ) will be scheduled in at least fClwk days. In this equation, it was necessary to define a time horizon different from the rest of the model to prevent the sum, for example, of 3 daily slots beginning on day 248 (in this case, the solver would try to add until day 251, which would be greater than the planning horizon). In other words, it is created for all periods excluding the last fllwk days (in this case, 250 - $\underline{\text { fClwk }) \text {. }}$

Equations 23, 24 and 25 ensure, for any 5 consecutive days (week), that the model allows an allocation of up to $\overline{\mathrm{nRoomwk}}$ rooms, up to $\overline{\mathrm{nAnwk}}$ anesthetists and up to $\overline{\mathrm{nEqwk}}_{\mathrm{e}}$ of equipment.

\section{Tested scenarios}

The model presented in the previous section has parameters that haven't been presented so far and that have the role of assigning weights to the different scenarios and of considering business rules related to the minimum frequency of scheduling of the group of residents per week ( $\mathrm{fClwk}$ ), the maximum amount of rooms available in the week ( $\overline{\mathrm{nRoomwk}}$ ), the maximum number of anesthetists available in the week ( $\overline{\mathrm{nAnwk}}$ ), and the maximum amount of equipment (e) available in the week $\left(\overline{\mathrm{nEqwk}_{\mathrm{e}}}\right)$. These factors are relevant to our problem because they add internal rules of the hospital about weekly resource availability as well as the ideal frequency stablished by the chief of vascular surgery. As we do not know if there are feasible solutions given these constrains, we do not consider these factors on the first 10 scenarios. If we obtain feasible solutions on these scenarios, we will add these factors to bring the solution closer to reality.

In our operating room planning a time horizon of 250 days was considered and the current business rules are: $\mathrm{fClwk}=3, \overline{\mathrm{nRoomwk}}=8, \overline{\mathrm{nAnwk}}=4$ and $\overline{\mathrm{nEqwk}}_{\mathrm{e}}=6$. Depending on its parameters, the triad combination of number of surgeons by type, minimum number of surgeries, and current business rules may not create feasible solutions, as it occurs in practice, because current rules are: $\underline{\mathrm{fClwk}}=3, \overline{\mathrm{nRoomwk}}=12, \overline{\mathrm{nAnwk}}=4$ and $\overline{\mathrm{nEqwk}}_{\mathrm{e}}=4$.

In order to assess not only the current business rules, but also the annual availability range of each resource and their criticality, we propose eleven scenarios in Table 12. The first column specifies the scenarios. Columns 2, 3, and 4 present the weights assigned to the operating room allocation ( Room $^{\mathrm{r}, \mathrm{d}}$ ), to the allocation of 


\begin{tabular}{|c|c|c|c|c|c|c|c|}
\hline \multirow[b]{2}{*}{ Scenario } & \multicolumn{3}{|c|}{ Weight, per allocative decision, related to: } & \multicolumn{4}{|c|}{ Weekly allocation business rules } \\
\hline & Surgery room & Anesthe-tist & Equip-ment & $\begin{array}{l}\text { Minimum } \\
\text { Frequency }\end{array}$ & $\begin{array}{l}\text { Maximum } \\
\text { number of } \\
\text { rooms }\end{array}$ & $\begin{array}{l}\text { Maximum } \\
\text { number of } \\
\text { anesthetists }\end{array}$ & $\begin{array}{l}\text { Maximum } \\
\text { amount of } \\
\text { equipment }\end{array}$ \\
\hline 1 & $10^{6}$ & $10^{3}$ & 1 & 0 & 10 & 10 & 10 \\
\hline 2 & 1 & $10^{3}$ & $10^{6}$ & 0 & 10 & 10 & 10 \\
\hline 3 & $10^{3}$ & $10^{6}$ & 1 & 0 & 10 & 10 & 10 \\
\hline 4 & 1 & $10^{6}$ & $10^{3}$ & 0 & 10 & 10 & 10 \\
\hline 5 & $10^{3}$ & $10^{3}$ & 1 & 0 & 10 & 10 & 10 \\
\hline 6 & 1 & $10^{3}$ & $10^{3}$ & 0 & 10 & 10 & 10 \\
\hline 7 & 1000 & 1 & $10^{3}$ & 0 & 10 & 10 & 10 \\
\hline 8 & 1 & 1 & 1 & 0 & 10 & 10 & 10 \\
\hline 9 & $10^{6}$ & $10^{3}$ & 1 & 3 & 8 & 8 & 8 \\
\hline 10 & $10^{6}$ & $10^{3}$ & 1 & 3 & 8 & 7 & 6 \\
\hline 11 & $10^{6}$ & $10^{3}$ & 1 & 3 & 8 & 4 & 6 \\
\hline
\end{tabular}

anesthetists $\left(\mathrm{AnSu}^{\mathrm{r}, \mathrm{d}}\right)$ and to the allocation of equipment (EqDaye $\left.{ }_{\mathrm{e}}^{\mathrm{r}, \mathrm{d}}\right)$. Columns 5, 6, 7, and 8 present the parameter values that have been adopted for each business rule.

Although only the last scenario has a "practical value", all responses allow us to evaluate which rules have more impact, and which ones interfere little in programming. From this, we may inform the decision-maker as to which rules could be disregarded, reinforced, adopted or negotiated with other clinics or with the head of the operating room.

In this case, taking as example scenario 1 of Table 12, the solver will allocate the team of surgeons from the same residency year in as few rooms as possible (highest weight assigned in scenario 1). Then, once the number of rooms is defined, the solver will seek the least amount of anesthetist allocation (intermediate weight in scenario 1), by reallocating the surgeries in each room and in each day. At the end, after the number of rooms and anesthetists are specified, the solver will seek the least amount of equipment allocation (lower in scenario 1). Moreover, in this scenario, there is no obligation to schedule the group of residents in every week and up to two rooms available on each of the five days of the week are considered. In other words, there are 10 rooms which may all have anesthetists and equipment in the week if necessary, even if this is not desirable.

\section{Results and discussion}

In Table 13, the first column designates the scenario and the second presents, nominally, the order of the adopted resource prioritization (translating "the weights" shown in Table 12). The third and fourth column present the size of the model, that is, the number of decision variables (being whole or binaries) and how many constraints were used respectively. Given that a minimum frequency value of scheduling of the group of residents week has not been established ( $\underline{\mathrm{fClwk}}=0)$ in scenarios 1 to 8 , constraint 21 is not active in these cases, and they have the same number of decision variables and constraints.

The fifth column presents the resolution times of the scenarios and the sixth column presents their respective gaps. These gaps are the percentage difference between the result found by linear relaxation (fractional solution without "practical value") and the best whole solution (allocation of groups of residents, for example), found during the resolution time. In case the gap reaches the value of $0.00 \%$, it means that the best whole solution found is the optimal solution.

The results of the best whole solutions found for each scenario are presented in columns 7, 8, 9, and 10. These solutions specify the time horizon of 250 days, the average use and the smaller number of rooms (\# Rooms), the number of rooms with anesthetist (\# Rooms with anesthetist) and the number of rooms with equipment (\# Rooms with equipment), which refer, in the model, to the terms $\sum_{\mathrm{r}, \mathrm{d}} \mathrm{Room}^{\mathrm{r}, \mathrm{d}}, \sum_{\mathrm{r}, \mathrm{d}}^{\mathrm{AnSu}} \mathrm{u}^{\mathrm{r}, \mathrm{d}}$ and $\sum_{\mathrm{e}, \mathrm{r}, \mathrm{d}} \mathrm{EqSu}_{\mathrm{e}}^{\mathrm{r}, \mathrm{d}}$, respectively.

One may observe that, in order to carry out the surgeries defined by the regulation and the preceptor in the first five scenarios, the amount of allocated resources vary in the intervals from 273 to 347 for rooms, from 224 to 279 for rooms with anesthetists, and from 200 to 310 for rooms with equipment. In this case, as the surgical service in question currently has 8 operating rooms during the week (a rule defined by the direction of the surgical center), and therefore 400 rooms in the year (up to 2 surgery rooms per day up to 8 rooms per week during the 250 days), it can be stated that this constraint of rooms (Equation 22) does not limit the space of viable solutions. 


\begin{tabular}{|c|c|c|c|c|c|c|c|c|c|}
\hline \multirow{3}{*}{$\begin{array}{l}\text { Scenario } \\
\text { results }\end{array}$} & \multicolumn{3}{|c|}{ Input data } & \multicolumn{6}{|c|}{ Model answers } \\
\hline & \multirow{2}{*}{$\begin{array}{l}\text { Objective function } \\
\text { Resource Criticality } \\
\text { Order (Hierarchy) }\end{array}$} & \multicolumn{2}{|c|}{ Model Size } & \multirow{2}{*}{$\begin{array}{c}\begin{array}{c}\text { Computational } \\
\text { resource }\end{array} \\
\begin{array}{c}\text { Solution time } \\
\text { (in seconds) }\end{array}\end{array}$} & \multirow{2}{*}{$\begin{array}{c}\begin{array}{c}\text { General } \\
\text { solutions }\end{array} \\
\text { Gap (\%) }\end{array}$} & \multicolumn{4}{|c|}{ Sizing model answers } \\
\hline & & $\begin{array}{l}\text { \# decision } \\
\text { variables }\end{array}$ & $\begin{array}{c}\# \\
\text { Constraints }\end{array}$ & & & $\begin{array}{c}\text { Average } \\
\text { usage } \\
(\%)\end{array}$ & \# Rooms & $\begin{array}{c}\# \\
\text { Anesthetists }\end{array}$ & $\begin{array}{c}\# \\
\text { Equipment }\end{array}$ \\
\hline 1 & $\begin{array}{l}\text { Room; anesthetist; } \\
\text { equipment }\end{array}$ & 52,250 & 70,621 & 11.456 .4 & 1.48 & 86.9 & 285 & 285 & 262 \\
\hline 2 & $\begin{array}{l}\text { Equipment; anesthetist; } \\
\text { room }\end{array}$ & 52,250 & 70,621 & $10,026.2$ & 0.03 & 73.3 & 339 & 274 & 200 \\
\hline 3 & $\begin{array}{l}\text { Anesthetist; room; } \\
\text { equipment }\end{array}$ & 52,250 & 70,621 & $12,340.2$ & 4.39 & 73.3 & 344 & 230 & 333 \\
\hline 4 & $\begin{array}{l}\text { Anesthetist; equipment; } \\
\text { room }\end{array}$ & 52,250 & 70,621 & $10,178.3$ & 4.39 & 69.1 & 364 & 230 & 310 \\
\hline 5 & $\begin{array}{l}\text { Room and anesthetist; } \\
\text { equipment }\end{array}$ & 52,250 & 70,621 & $19,633.1$ & 11.55 & 83.5 & 297 & 269 & 270 \\
\hline 6 & $\begin{array}{l}\text { Anesthetist and } \\
\text { equipment; room }\end{array}$ & 52,250 & 70,621 & $68,774.9$ & 12.19 & 70.1 & 354 & 278 & 200 \\
\hline 7 & $\begin{array}{l}\text { Room and equipment; } \\
\text { anesthetist }\end{array}$ & 52,250 & 70,621 & $69,962.0$ & 2.48 & 84.6 & 293 & 293 & 200 \\
\hline 8 & No hierarchy & 52,250 & 70,621 & $106,748.5$ & 10.44 & 84.9 & 290 & 280 & 200 \\
\hline 9 & $\begin{array}{l}\text { Room; anesthetist; } \\
\text { equipment }\end{array}$ & 52,250 & 70,612 & $60,038.6$ & 1.48 & 86.9 & 285 & 285 & 262 \\
\hline 10 & $\begin{array}{l}\text { Room; anesthetist; } \\
\text { equipment }\end{array}$ & 52,250 & 70,612 & $60,051.3$ & 1.83 & 86.6 & 286 & 286 & 254 \\
\hline 11 & $\begin{array}{l}\text { Room; anesthetist; } \\
\text { equipment }\end{array}$ & 52,250 & 70,612 & & & Infeasibl & solution & & \\
\hline
\end{tabular}

However, due to the scarcity of other resources (anesthetists and equipment), the direction of the surgical center assigns, in the weekly horizon, only 3 days of rooms with anesthetists and 3 days of rooms with equipment. From the results of the model, it is concluded that these two rules make any solution impossible. Considering the annual horizon ( 250 days), these resources would be available only in 150 days ( 3 days a week over 50 weeks) whereas at least 224 rooms with anesthetist and 262 rooms with equipment (scenario 4) or 247 rooms with anesthetist (scenario 2) would be required.

So, the only resource that would not make sense to prioritize (assign greater weight) in detriment of others would be the surgery rooms. However, scenario 1 was chosen as ideal by the chief surgeon of the vascular surgery service with the argument that other surgical services receive fewer rooms in the week and this kind of solution could possibly free room spaces to be allocated according to other rules or even just to be available.

Thus, considering the priority order proposed in scenario 1, scenario 9 was built by changing the minimum frequency of scheduling of the group of residents per week to $3(\mathrm{fClwk}=3)$, and by changing the maximum amount of rooms, anesthetics and equipment (e) assigned in the week to $8(\overline{\mathrm{nRoomwk}}=\overline{\mathrm{nAnwk}}=\overline{\mathrm{nAnwk}}=8)$.

Finally, scenario 10 was obtained by changing the previous parameters, respectively, to 3, 8, 7, and 6 . Therefore, in the last scenario, the goal is to bring the last two parameters closer to the current business rules and check the impact of this change in the found solution. By the preceptor's choice, scenario 10 was admitted as the ideal one, due to the fact it is the closest to the current set of rules (scenario 11), which has no feasible solution.

\section{Conclusion}

The present research proposed a model of resource allocation to meet the minimum training criteria required by current legislation and by the chief surgeon of a vascular surgery service. Thus, besides efficiently designing the planning and scheduling of the elective surgeries of this service (the research question per se), it was possible to evaluate the pertinence of current business rules of the surgical center and of business rules internal to the service, responding, at a tactical level (Master Surgical Schedule), when each group of residents should be allocated in which room, with which resources, and how many times it should be scheduled to perform any surgery in a weekly horizon.

The results, for different orders of resource prioritization, indicate that intervals of 273 to 347 surgery rooms, 224 to 279 rooms with anesthetics, and 200 to 310 rooms with equipment are necessary annually for the accomplishment of the minimum number of surgeries necessary for the approval in the residence program 
To ensure a feasible and efficient surgical planning, which, for each scenario, involved different logics of resource prioritization, the usage ratio of surgery rooms ranged from $67.6 \%$ to $85.6 \%$.

Future works could incorporate constraints that take into account not only the availability of staff and ergonomic regulations (Erhard et al., 2018), but also criteria related to social preferences (Roland \& Riane, 2011) among which one may mention: no major surgeries on Fridays, more specific rules for scheduling in the weekly horizon (for example: that the surgeon should be scheduled just on Mondays, Wednesdays and Fridays or just on Tuesdays, Thursdays only in the morning or only in the afternoon).

\section{References}

Abdelrasol, Z., Harraz, N., \& Eltawil, A. (2014). Operating room scheduling problems: a survey and a proposed solution framework. In H. K. Kim, M. A. Amouzegar, \& S.-1. Ao (Eds.), Transactions on engineering technologies (pp. 717-731). Dordrecht: Springer.

Assad, D. B. N. (2017). Planejamento e programação de cirurgias eletivas: estudo de caso em um hospital universitário (Master’s dissertation). Pontifícia Universidade Católica do Rio de Janeiro, Rio de Janeiro.

Assad, D. B. N., Hamacher, S., \& Spiegel, T. (2018a). Vascular elective surgeries planning and scheduling: a case study at a teaching hospital. In Operations Management for Social Good. 2018 POMS International Conference in Rio. Springer Proceedings Business, Economics. USA: Springer.

Assad, D. B. N., Silva, A. C., Spiegel, T., \& Cardoso, L. (2018b). Planejamento tático de centro cirúrgico: a decisão de alocação de salas cirúrgicas. In D. F. Andrade. (Ed.), Gestão da produção em foco (Vol. 13, pp. 229-240). Belo Horizonte: Editora Poisson.

Barbagallo, S., Corradi, L., de Ville de Goyet, J., lannucci, M., Porro, 1., Rosso, N., Tanfani, E., \& Testi, A. (2015). Optimization and planning of operating theatre activities: an original definition of pathways and process modeling. BMC Medical Informatics and Decision Making, 15(1), 38. http://dx.doi.org/10.1186/s12911-015-0161-7. PMid:25982033.

Beliën, J., Demeulemeester, E., \& Cardoen, B. (2009). A decision support system for cyclic master surgery scheduling with multiple objectives. Journal of Scheduling, 12(2), 147-161. http://dx.doi.org/10.1007/s10951-008-0086-4.

Bisschop, J., \& Roelofs, M. (2011). AIMMS 3.14: the user guide. Netherlands, Haarlem: Paragon Decision Technology BV.

Brasil. Ministério da Educação. (2006, May 17). Resolução CNRM n 02/2006, de 17 de maio de 2006. Dispõe sobre requisites mínimos dos Programas de Residência Médica e dá outras providências. Diário Oficial da República Federativa do Brasil. Retrieved in 20 May 2017, from http://portal.mec.gov.br/index.php?option=com_docman\&view=download\&alias=100951-resolucao-cnrm-n-2-de-17de-maio-de-2006\&category_slug=novembro-2018-pdf\&ltemid=30192

Day, R., Garfinkel, R., \& Thompson, S. (2012). Integrated block sharing: a win-win strategy for hospitals and surgeons. Manufacturing \& Service Operations Management: M \& SOM, 14(4), 567-583. http://dx.doi.org/10.1287/msom.1110.0372.

Erhard, M., Schoenfelder, J., Fügener, A., \& Brunner, J. 0. (2018). State of the art in physician scheduling. European Journal of Operational Research, 265(1), 1-18. http://dx.doi.org/10.1016/j.ejor.2017.06.037.

He, B., Dexter, F., Macario, A., \& Zenios, S. (2012). The timing of staffing decisions in hospital operating rooms: incorporating workload heterogeneity into the newsvendor problem. Manufacturing \& Service Operations Management: M \& SOM, 14(1), 99-114. http:// dx.doi.org/10.1287/msom.1110.0350.

Hulshof, P. J., Kortbeek, N., Boucherie, R. J., Hans, E. W., \& Bakker, P. J. (2012). Taxonomic classification of planning decisions in health care: a structured review of the state of the art in OR/MS. Health Systems (Basingstoke, England), 1(2), 129-175. http:// dx.doi.org/10.1057/hs.2012.18.

Jeang, A., \& Chiang, A. J. (2012). Economic and quality scheduling for effective utilization of operating rooms. Journal of Medical Systems, 36(3), 1205-1222. http://dx.doi.org/10.1007/s10916-010-9582-0. PMid:20814721.

M'Hallah, R., \& Al-Roomi, A. H. (2014). The planning and scheduling of operating rooms: a simulation approach. Computers \& Industrial Engineering, 78, 235-248. http://dx.doi.org/10.1016/j.cie.2014.07.022.

Mendes, C. D. A., Martins, A. D. A., Teivelis, M. P., Kuzniec, S., \& Wolosker, N. (2014). Public private partnership in vascular surgery. Einstein (Sao Paulo, Brazil), 12(3), 342-346. http://dx.doi.org/10.1590/s1679-45082014gs3029. PMid:25295457.

Miguel, P. A. C. (2007). Estudo de caso na engenharia de produção: estruturação e recomendações para sua condução. Revista Produção, 17(1), 216-229. http://dx.doi.org/10.1590/S0103-65132007000100015.

Paul, J. A., \& Jotshi, A. (2013). Efficient operating room redesign through process improvement and optimal management of scheduled and emergent surgeries. International Journal of Mathematics in Operational Research, 5(3), 317-344. http://dx.doi.org/10.1504/ IJMOR.2013.053626.

Persson, M., \& Persson, J. A. (2007). Optimization modelling of hospital operating room planning: Analyzing strategies and problem settings. In Operational Research for Health Policy: Making Better Decisions, 31st Annual Conference of the European Working Group on Operational Research Applied to Health Services (pp. 137). Bern, Switzerland: Peter Lang International Academic Publishers.

Rais, A., \& Viana, A. (2011). Operations research in healthcare: a survey. International Transactions in Operational Research, 18(1), 1-31. http://dx.doi.org/10.1111/j.1475-3995.2010.00767.x.

Roland, B., \& Riane, F. (2011). Integrating surgeons' preferences in the operating theatre planning. European Journal of Industrial Engineering, 5(2), 232-250.

Saadouli, H., Jerbi, B., Dammak, A., Masmoudi, L., \& Bouaziz, A. (2015). A stochastic optimization and simulation approach for scheduling operating rooms and recovery beds in an orthopedic surgery department. Computers \& Industrial Engineering, 80, 72-79. http:// dx.doi.org/10.1016/j.cie.2014.11.021.

Saadouli, H., Masmoudi, M., Jerbi, B., \& Dammak, A. (2014, November). An optimization and Simulation approach for Operating Room scheduling under stochastic durations. In 2014 International Conference on Control, Decision and Information Technologies (CoDIT) (pp. 257-262). USA: IEEE. http://dx.doi.org/10.1109/CoDIT.2014.6996903. 
Silva, A. C., Assad, D. B., \& Spiegel, T. (2018). Capacity decision in emergency hospital operation rooms: sizing using simulation. In M. Ebrahimi (Ed.), Modeling and simulation techniques for improved business processes (pp. 140-155). Hershey, PA: 1Gl Global. http:// dx.doi.org/10.4018/978-1-5225-3226-2.ch006.

Spiegel, T., \& Assad, D. B. (2018). Operations model for trauma centers: multiple case study. International Journal of Public Health Management and Ethics, 3(1), 1-13. http://dx.doi.org/10.4018/1JPHME.2018010101.

Sufahani, S., \& lsmail, Z. (2014). A real scheduling problem for hospital operation room. Applied Mathematical Sciences, 8(114), 56815688. http://dx.doi.org/10.12988/ams.2014.46413.

Vähätalo, M., \& Kallio, T. J. (2015). Organising health services through modularity. International Journal of Operations \& Production Management, 35(6), 925-945. http://dx.doi.org/10.1108/IJOPM-12-2013-0523.

Van Oostrum, J. M., Van Houdenhoven, M., Hurink, J. L., Hans, E. W., Wullink, G., \& Kazemier, G. (2008). A master surgical scheduling approach for cyclic scheduling in operating room departments. OR-Spektrum, 30(2), 355-374. http://dx.doi.org/10.1007/s00291006-0068-x.

Van Sambeek, J. R. C., Cornelissen, F. A., Bakker, P. J. M., \& Krabbendam, J. J. (2010). Models as instruments for optimizing hospital processes: a systematic review. International Journal of Health Care Quality Assurance, 23(4), 356-377. http://dx.doi. org/10.1108/09526861011037434. PMid:20535906.

Villarreal, M. C., \& Keskinocak, P. (2016). Staff planning for operating rooms with different surgical services lines. Health Care Management Science, 19(2), 144-169. http://dx.doi.org/10.1007/s10729-014-9307-x. PMid:25366968.

Wang, Y., Tang, J., \& Qu, G. (2010). A genetic algorithm for solving patient-priority-based elective surgery scheduling problem. In Y. Wang, J. Tang, \& G. Qu. Life system modeling and intelligent computing (pp. 297-304). Berlin: Springer. http://dx.doi. org/10.1007/978-3-642-15597-0_33.

Yin, R. K. (2001). Estudo de caso: planejamento e métodos (2. ed.). Porto Alegre: Bookman. 